\title{
Synthesis of some heterocyclic compounds based on (2, 3-dioxo-2, 3- dihydro-1H-indol-1-yl) acetyl acetic acid derivatives
}

\author{
M. M. H. Arief $^{1}$, M. H. M. Ahmed ${ }^{1}$, A. A. Said ${ }^{2}$, N. M. M. Selim ${ }^{2}{ }^{2}$ \\ ${ }^{1}$ Department of Chemistry, Benha University, Benha, Egypt, B.O.: 13518 \\ ${ }^{2}$ Agricultural Pesticide Laboratory, Agricultural Research Centre \\ *Corresponding author_E-mail: nahed_slem@yahoo.com
}

\begin{abstract}
Reactions of isatin- $\mathrm{N}$-acetylchloride 2 with equivalent amount of hydrazine hydrate gave 2-(2, 3-dioxo-2, 3-dihydro1H-indol-1-yl) acetohydrazide 3 which was then cyclized to give [1, 2, 4] triazino [4, 3-a] indole-3, $10(2 \mathrm{H}, 4 \mathrm{H})$-dione 5 but when 2 reacted with excess of hydrazine hydrate it give 2[(2, 3-bishydrazono)-2, 3-dihydro-1H-indol-1-yl] acetohydrazide 4. Isothiocyanate derivative 6 was prepared from the corresponding acid chloride and ammonium thiocyanate in acetone. The reactions of isothiocyanate with anthranilic acid, glycine, benzoyl glycine, hydrazine hydrate and benzoyl hydrazine were also investigated. The condensation reaction of benzoyl glycine with isothiocyanate in the presence of benzaldehyde gave $\mathbf{1 6}$ which was easily cyclized to give $\mathbf{1 7}$.
\end{abstract}

Keywords: Isatin, thionyl chloride, chloro acetic acid, hydrazine hydrate, acetic anhydride, ammonium thiocyanate, anthranilic acid, glycine, benzoyl glycine and benzaldehyde.

\section{Introduction}

Isatin has been used for the synthesis of fused indole derivatives such as indothiazoles [1], thiadiazinoindoles [2], pyrazinoindoles [3], trindolobenzenes [4], indoloquinazoline [5], 1,2,4-triazinoindoles [6-10], indolopteridine derivatives [11], oxindole derivatives [12,13] and spiro[dihydropyridine-oxindoles] [14]. Isatin derivatives can suffer nucleophilic attack at position C-2 and/or C-3. The chemoselectivity of these reactions depends on the nature of the nucleophile, the substituents attached to isatin nucleus especially those bonded to the nitrogen atom, as well as, upon the solvent and temperature employed [15]. Isatins are an important group of heterocyclic compounds which are biologically active and of significant importance in medicinal chemistry and spiro [indole] thiadiazole derivatives [16$18]$.

In this project we have been concerned with preparation of some heterocyclic compounds containing isatin moiety and tested their biological activities. The synthetic procedures adopted to obtain the target compounds are depicted in Scheme (1).

\section{Results and discussion}

Thus isatin reacted with chloro-acetic acid in presence of anhydrous pot.carbonate $\left(\mathrm{K}_{2} \mathrm{CO}_{3}\right)$ in dry acetone to give isatin $\mathrm{N}$-acetic acid 1. When thionyl chloride reacted with isatin-N acetic acid it afforded isatin-N-acetyl chloride 2. Treatment of $\mathbf{2}$ with (equivalent amount) hydrazine hydrate in refluxing dry benzene it afforded 2-(2, 3-dioxo-2, 3dihydro-1H-indol-1-yl) acetohydrazide 3. On the other hand when the reaction of isatin- $\mathrm{N}$-acetyl chloride 2 was carried out with excess hydrazine hydrate in refluxing dry benzene it give 2[(2, 3-bishydrazono)-2, 3-dihydro-1H-indol-1-yl] acetohydrazide 4.

When compound $\mathbf{3}$ was refluxed in freshly distilled acetic anhydride it cyclized to yield triazine derivative $\mathbf{5}$. Also, isothiocyanate $\mathbf{6}$ was synthesized in situe via the reaction of acid chloride $\mathbf{2}$ with ammonium thiocyanate. Compound $\mathbf{6}$ was used as a stating material to synthesize some new heterocyclic compounds. Thus, 2- (\{[2, 3- dioxo -2, 3-dihydro $1 \mathrm{H}$ - indol -1-yl] acetyl\} carbamothioyl) amino) benzoic acid 7 was obtained upon treatment of anthranilic acid with 
isothiocyanate $\mathbf{6}$ in refluxing dry acetone. Also when compound 7 was refluxed in freshly destilled acetic anhydride it cyclized to 8 .

When compound $\mathbf{6}$ was reflxed with glycine in dry acetone and few drops of dry pyridine; it yielded compound $\mathbf{9}$. Also, when compound $\mathbf{6}$ was allowed to react with benzoyl glycine in boiling dry acetone and few drops of dry pyridine, it afforeded [\{[(2,3- dioxo-2, 3 dihydro-1H-indol-1-yl) acetyl] carbamothioyl $\}$ benzoyl -amino] acetic acid 10. Moreover, when compound $\mathbf{1 0}$ was refluxed in freshly distilled acetic anhydride, it yielded imidazolidine derivative 11. Treatment of compound $\mathbf{6}$ with hydrazine hydrate in boiling dry benzene, it afforded compound 12. When compound $\mathbf{1 2}$ was refluxed in freshly distilled acetic anhydride, it yielded 1-[(5-thioxo-4, 5-dihydro-1-H-1, 2, 4-triazol-3-yl) methyl]-1Hindole-2, 3-dione 13.

Furthermore, when benzoyl hydrazine was added to a solution of isothiocyanate 6 in boiling dry acetone it give 14. On the other hand when compound $\mathbf{1 4}$ was refluxed in freshly distilled acetic anhydride it gave 1-[2-oxo-2(3-phenyl-5thioxo-1, 5-dihydro-4 H-1, 2, 4-triazol-4-yl) ethyl]-1H-indole-2, 3-dione 15. Also, when isothiocyanate derivative 6 in dry acetone was added to benzoyl glycine and benzaldehyde in dry pyridine, it afforded compound 16. When compound 16 was refluxed in freshly distilled acetic anhydride it cyclized to give 1-[2-(3-benzoyl-4-benzylidene-5-oxo-2-thioxoimidazolidin-1-yl)-2-oxo-ethyl]-1H-indole-2,3-dione 17. The structures of 3-17 were confirmed by correct elemental analysis, IR, ${ }^{1} \mathrm{HNMR}$ and mass spectra.

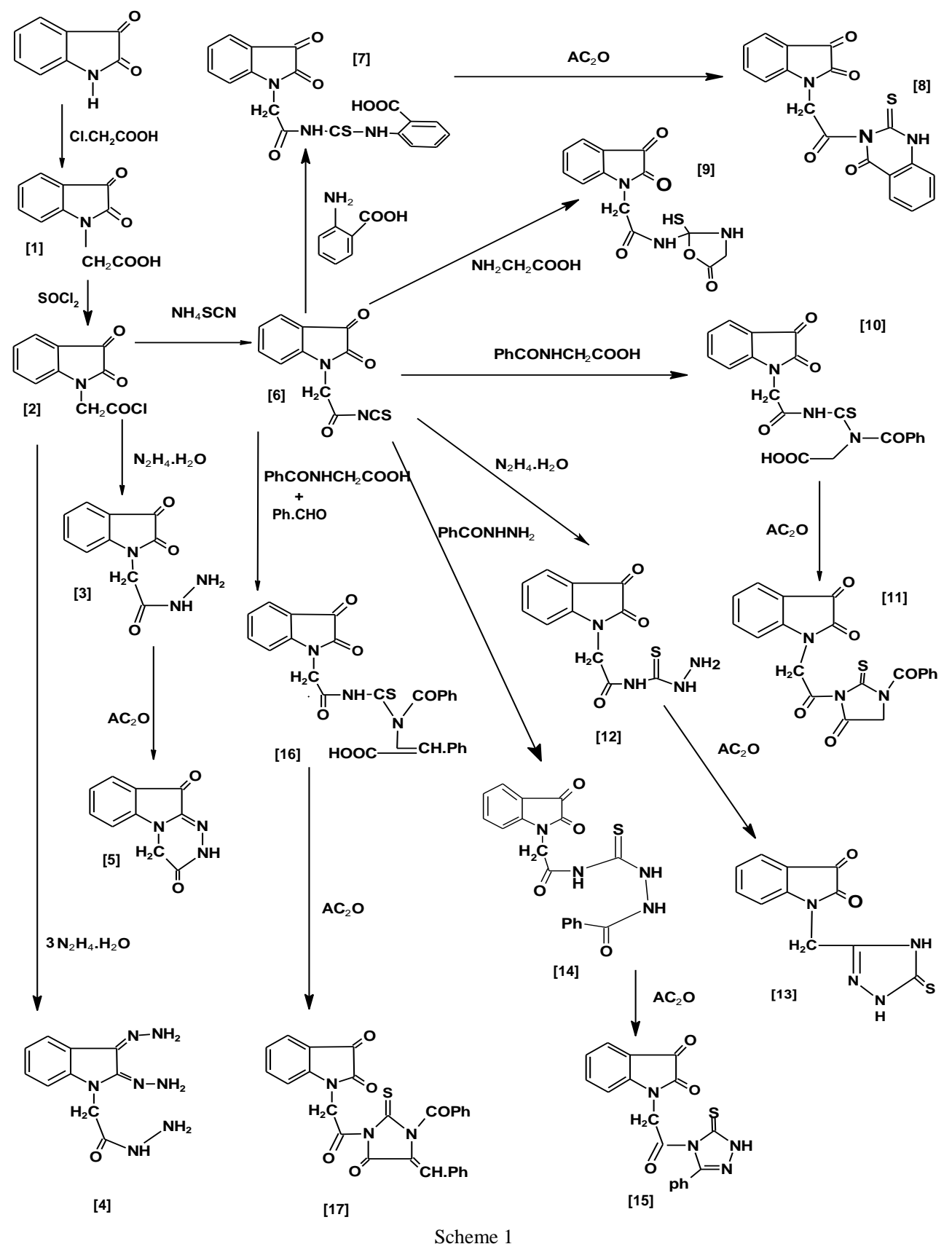




\section{Biological activity (Sensitivity tests) by Kirby-Bauer Method}

Antimicrobial activity of the tested samples was determined using a modified Kirby-Bauer disc diffusion method [19]. Briefly, $100 \mu \mathrm{l}$ of the test bacteria/fungi were grown in $10 \mathrm{ml}$ of fresh media unit they reached a count of approximately 108 cells $/ \mathrm{ml}$ for bacteria or 105 cells $/ \mathrm{ml}$ for fungi [20]. $100 \mu \mathrm{l}$ of microbial suspension was spread onto agar plates corresponding to the both in which they were maintained. Isolated colonies of each organism that might be playing a pathogenic role should be selected from primary agar plates and tested for susceptibility by disc diffusion method [21]. Disc diffusion method for filamentous fungi tested by using approved standard method (M38-A) developed by the (NCCLS 2002) [22] for evaluating the susceptibilities of filamentous fungi to antifungal agents. Disc diffusion method for yeasts developed by using approved standard method (M44-p) by the (NCCLS 2003) [23]. Plates inoculated with filamentous fungi as Aspergillus flavus at $25^{\circ} \mathrm{C}$ for 48 hours; Gram $(+)$ bacteria as Staphylococcus aureus, Bacillus subtilis; Gram (-) bacteria as Escherichia coli, Pseudomonas aeuroginosa they were incubated at $35-37{ }^{\circ} \mathrm{C}$ for $24-48$ hours and yeast as Candida albicans incubated at $30{ }^{\circ} \mathrm{C}$ for $24-48$ hours and, then the diameters of the inhibition zones were measured in millimeters [19]. Standard disc of Tetracycline (Antifungal agent), Amphotericin B (Antifungal agent) served as positive controls for antimicrobial activity but filter discs impregnated with $10 \mu \mathrm{l}$ of solvent (distilled water, chloroform, DMSO) were used as a negative control.

The agar used is Meuller-Hinton agar that is rigorously tested for composition and PH. Further the depth of the agar in the plate is a factor to be considered in the disc diffusion method. Blank paper disks (Schleicher \& Schuell, Spain) with a diameter of $8.0 \mathrm{~mm}$ were impregnated $10 \mu$ of tested concentration of the stock solutions. For the disc diffusion, the zone diameters were measured with slipping calipers of the National Committee for Clinical Laboratory Standards [24]. Agar-based methods such as Etest and disc diffusion can be good alternatives because they are simple and faster then broth-based methods $[25,26]$ in table (1) and figrs $(1,2)$.

\section{Conclusion}

From the structure-activity relationship it clear that compounds 3, 5, 8, 9, 14, and 17 showed the highest activity and it may be due to the acetohydrazide, thiourido and triazolo-moieties.

\begin{tabular}{|c|c|c|c|c|c|}
\hline \multirow{2}{*}{\multicolumn{2}{|c|}{ Sample }} & \multicolumn{4}{|c|}{ Inhibution zone diameter (mm/mg Sample) } \\
\hline & & $\begin{array}{c}\text { Escherichia coli } \\
(\mathrm{G}-)\end{array}$ & $\begin{array}{l}\text { Staphylococcus } \\
\text { aureus (G+) }\end{array}$ & $\begin{array}{c}\text { Aspergillus niger } \\
\text { (Fungus) }\end{array}$ & $\begin{array}{c}\text { Candida albicans } \\
\text { (Fungus) }\end{array}$ \\
\hline \multirow{3}{*}{$\begin{array}{l}\dot{\vec{D}} \\
\stackrel{\Xi}{ \pm} \\
\dot{\vec{s}}\end{array}$} & Control:DMF & 0.0 & 0.0 & 0.0 & 0.0 \\
\hline & $\begin{array}{c}\text { Tetracycline } \\
\text { Antibacterial agent }\end{array}$ & -- & -- & -- & -- \\
\hline & $\begin{array}{l}\text { Amphotericin B } \\
\text { Antifungal agent }\end{array}$ & -- & -- & 17 & 19 \\
\hline & 3 & 20 & 18 & 0.0 & 0.0 \\
\hline & 4 & 14 & 12 & 0.0 & 0.0 \\
\hline & 5 & 11 & 11 & 0.0 & 9.0 \\
\hline & 7 & 10 & 11 & 0.0 & 0.0 \\
\hline & 8 & 14 & 15 & 0.0 & 0.0 \\
\hline & 9 & 15 & 16 & 10 & 0.0 \\
\hline & 10 & 10 & 10 & 0.0 & 0.0 \\
\hline & 11 & 13 & 15 & 0.0 & 12 \\
\hline & 12 & 9 & 11 & 0.0 & 10 \\
\hline & 13 & 11 & 10 & 0.0 & 0.0 \\
\hline & 14 & 13 & 12 & 0.0 & 0.0 \\
\hline & 15 & 10 & 10 & 0.0 & 0.0 \\
\hline & 16 & 12 & 0.0 & 0.0 & 0.0 \\
\hline & 17 & 14 & 13 & 0.0 & 0.0 \\
\hline
\end{tabular}



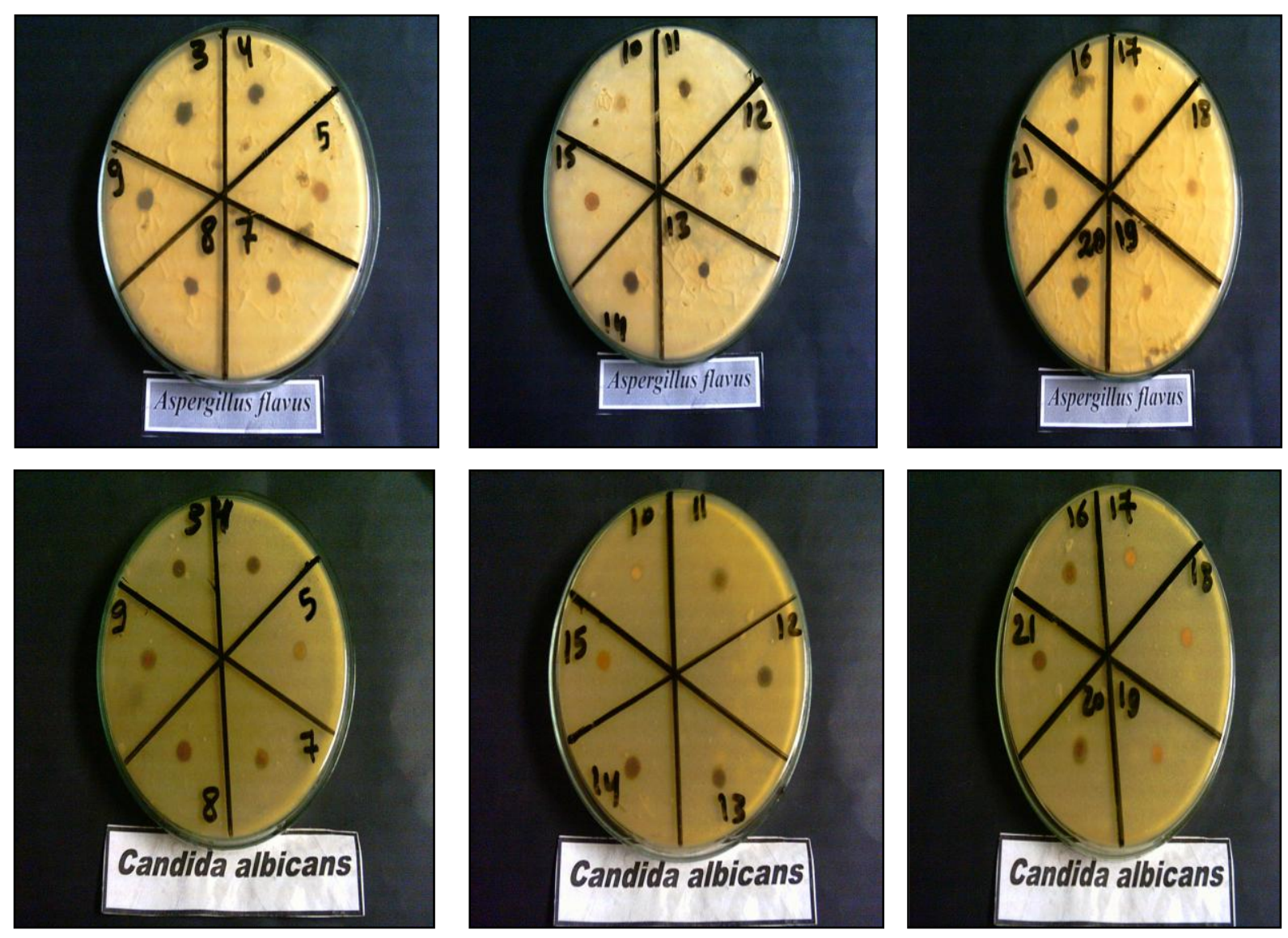

Fig. 1
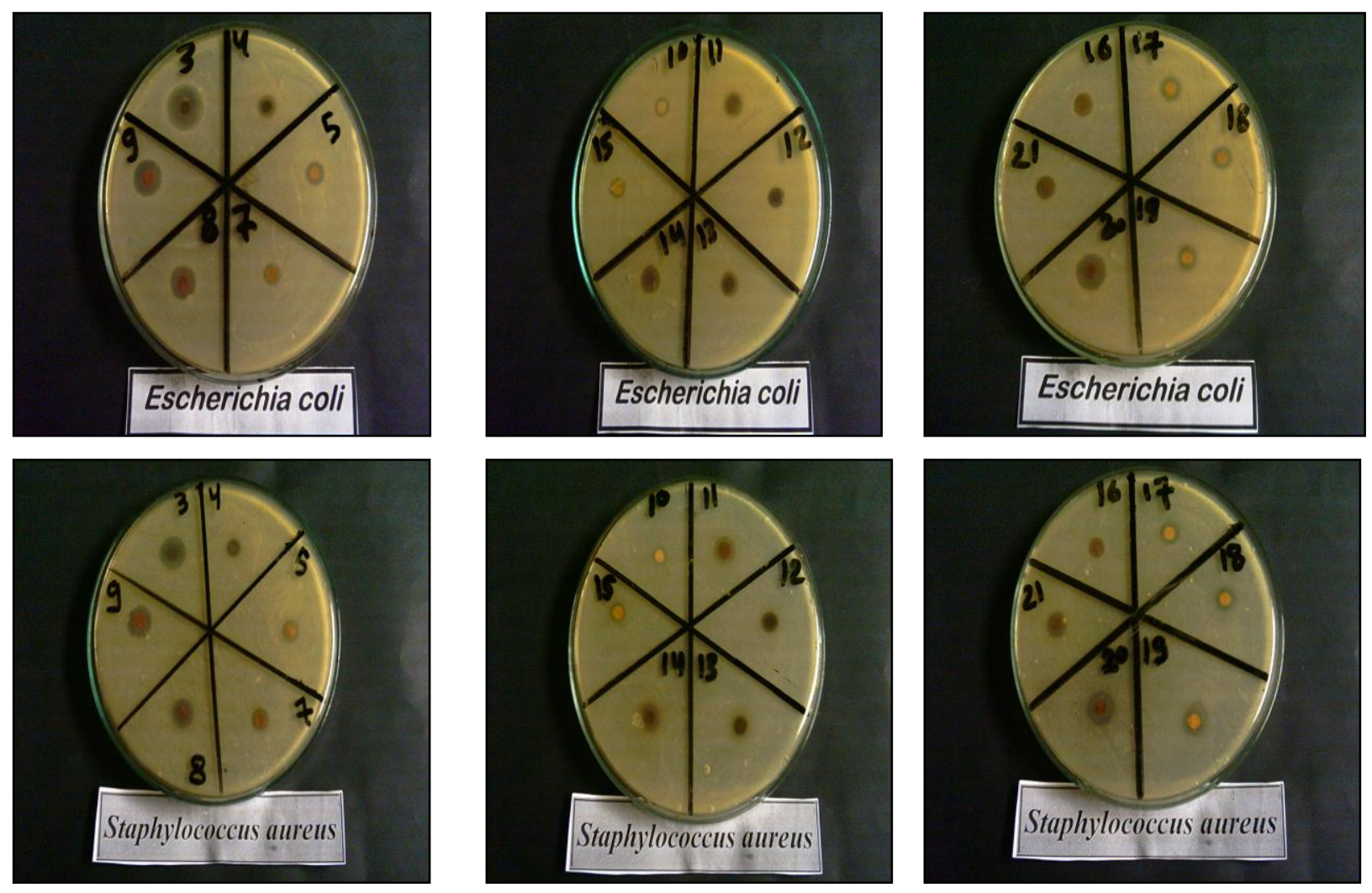

Fig. 2 


\section{Experimental part}

All melting points are uncorrected. IR spectra in $\mathrm{KBr}$ were recorded on a Shimadzu 470 spectrometer. ${ }^{1} \mathrm{HNMR}$ spectra were measured on a Varian Gemini $300 \mathrm{MHz}$ spectrometer using TMS as internal standard, chemical shifts in $\delta$-scale (ppm). Mass spectra were recorded on G-C/MS finnigan-MAT. Elemental analyses were carried out at the microanalysis unit, faculty of science Cairo University. The homogeneity of the synthesized compounds was controlled by TLC [using TLC aluminum silica gel $\mathrm{F}_{254}$ (Merck)] and Biological activity (Sensitivity tests) were carried out Cairo University by Kirby-Bauer Method.

Reaction of isatin with chloroacetic acid: Synthesis of isatin-N-acetic acid (1):

A mixture of isatin $(1.99 \mathrm{~g}, 10 \mathrm{mmole})$ and $(0.945 \mathrm{~g}, 10 \mathrm{mmole})$ chloroacetic acid in the present of (1.38 g, $10 \mathrm{mmole})$ anhydrous $\mathrm{K}_{2} \mathrm{CO}_{3}$ in dry acetone.The whole mixture was heated under reflux on water bath for 6 hrs to give isatin-Nacetic acid (1). The solid product which had separated was filtered. The excess solvent was removed under reduced pressure to give orange crystals which collected by filtration and recrystallized from ethanol, m.p $=113-115$, yield 96.7\%. Anal. Calcd. \% for $\mathrm{C}_{10} \mathrm{H}_{7} \mathrm{NO}_{4}$ (205): C, 58.54; H, 3.44; N, 6.83. Found \%: C, 58.52; H, 3.49; N, 6.79. IR (KBr) $\left(v_{\max }, \mathrm{cm}^{-1}\right): 3367,3318(\mathrm{OH}), 1725(\mathrm{C}=\mathrm{O})$ of acid, $1617(\mathrm{C}=\mathrm{O})$ of ketone. ${ }^{1} \mathrm{HNMR}\left(\mathrm{DMSO}-\mathrm{d}_{6}\right): \delta 11.03(\mathrm{~s}, 1 \mathrm{H}, \mathrm{COOH}$, exchangeable with $\left.\mathrm{D}_{2} \mathrm{O}\right), 7.6-6.8(\mathrm{~m}, 4 \mathrm{H}, \mathrm{ArH}), 3.4\left(\mathrm{~s}, 2 \mathrm{H}, \mathrm{CH}_{2}\right)$.

Reaction of isatin-N-acetic acid with thionyl chloride: Synthesis of isatin-N-acetyl chlorid (2)

A mixture of isatin-N-acetic acid (1) $(2.05 \mathrm{~g}, 10 \mathrm{mmole})$ and $5 \mathrm{ml}$ thionyl chloride was heated under reflux on water bath for $2 \mathrm{hrs}$; the excess thionyl chloride was removed by distillation to give isatin-N- chloro acetic acid (2).

Reaction of (2) with hydrazine hydrate: Synthesis of 2-(2, 3-dioxo-2, 3-dihydro-1H-indol-1-yl) acetohydrazide (3) A mixture (2) (2.23 g, 10 mmole) was added to a solution of the equivalent amount ( $0.5 \mathrm{ml}, 10$ mmole $)$ of hydrazine hydrate in $30 \mathrm{ml}$ of dry benzene the reaction mixture was refluxed for $1 / 4 \mathrm{hr}$ and recrystallized from ethanol to give (3), m.p $=280-282$, yield $=88 \%$. Anal. Calcd. \% for $\mathrm{C}_{10} \mathrm{H}_{9} \mathrm{~N}_{3} \mathrm{O}_{3}(219): \mathrm{C}, 54.79 ; \mathrm{H}, 4.14 ; \mathrm{N}, 19.17$. Found \%: C, 54.71; $\mathrm{H}$, 4.19; N, 19.11. IR (KBr) $\left(v_{\max }, \mathrm{cm}^{-1}\right): 3365\left(\mathrm{NH}_{2}\right), 3187(\mathrm{NH}), 1688$ (CO of imid). MS, m /z (\%): $219\left(\mathrm{M}^{+}, 3.49\right)$.

Reaction of isatin-N-chloro acetyl chloride with excess hydrazine hydrate: give 2[(2, 3-bishydrazono)-2, 3dihydro-1H-indol-1-yl] acetohydrazide (4)

A mixture of isatin- $\mathrm{N}$ - chloro acetyl chloride (2) (2.23 g, 10 mmole) and excess (3 moles) (1.5 ml, $10 \mathrm{mmole})$ of hydrazine hydrate in $30 \mathrm{ml}$ of dry benzene, the reaction mixture was refluxed for 10 min the product obtained was recrystallized from ethanol to give (4), m.p $=160-162$, yield $=91 \%$. Anal. Calcd. $\%$ for $\mathrm{C}_{10} \mathrm{H}_{13} \mathrm{~N}_{7} \mathrm{O}(247)$ : $\mathrm{C}, 48.58 ; \mathrm{H}$, 5.30; N, 39.65. Found \%: C, 48.49; H, 5.39; N, 39.61. IR (KBr) (vmax, cm-1): $3355\left(\mathrm{NH}_{2}\right), 3152(\mathrm{NH}), 1681(\mathrm{CO}$ of imid), 1590, $(\mathrm{C}=\mathrm{N}) .{ }^{1} \mathrm{HNMR}\left(\mathrm{DMSO}_{6}\right)$ : $\delta 10.5\left(\mathrm{t}, 1 \mathrm{H}, \mathrm{NH}\right.$, exchangeable with $\left.\mathrm{D}_{2} \mathrm{O}\right), 9.5\left(\mathrm{~d}, 1 \mathrm{H}, \mathrm{NH}_{2}\right.$, exchangeable with $\left.\mathrm{D}_{2} \mathrm{O}\right), 7.3-6.8(\mathrm{~m}, 4 \mathrm{H}, \mathrm{ArH})$ and $2.2\left(\mathrm{~s}, 2 \mathrm{H}, \mathrm{CH}_{2}\right)$.

cyclization of (3) with freshly acetic anhydride: Synthesis of [1,2,4]triazino[4,3-a]indole-3,10(2H,4H)-dione(5)

Compound (3) (1.08 g, 4.93 mmole) was refluxed in freshly distilled acetic anhydride (10 ml) for $2 \mathrm{hr}$. Then cooled and poured into ice-water the precipitate obtained was filtered off, washed with water and recrystallized from ethanol to give (5), m.p $=110-112$, yield $=68 \%$. Anal. Calcd. $\%$ for $\mathrm{C}_{10} \mathrm{H}_{7} \mathrm{~N}_{3} \mathrm{O}_{2}$ (219): C, 59.70; $\mathrm{H}, 3.51 ; \mathrm{N}, 20.89$. Found \%: C, 59.72; H, 3.52; N, 20.92. IR (KBr) $\left(v_{\max }, \mathrm{cm}^{-1)}\right.$ : $3251(\mathrm{NH}), 1707$ (CO amid). ${ }^{1} \mathrm{HNMR}\left(\mathrm{DMSO}-\mathrm{d}_{6}\right): \delta 12.1(\mathrm{~s}, 1 \mathrm{H}, \mathrm{NH}$, exchangeable with $\left.\mathrm{D}_{2} \mathrm{O}\right), 8.1-7.3(\mathrm{~m}, 4 \mathrm{H}, \mathrm{ArH}), 3.3\left(\mathrm{~s}, 2 \mathrm{H}, \mathrm{CH}_{2}\right)$.

Reaction of (2) with ammonium thiocyanate: Synthesis of (2, 3-dioxo-2, 3-dihydro-1H-indol-1-yl) acetyl isothiocyanate (6)

To a stirred solution of acid chlorides (2) (2.23 g, $10 \mathrm{mmole})$ in dry acetone $(50 \mathrm{ml})$, solid ammonium thiocyanate $(0.76$ $\mathrm{g}, 10 \mathrm{mmole})$ was added. The reaction mixture was stirred for $(1 \mathrm{hr})$ at room temperature, and then filtered off to leave a clear solution of acetone to give (6).

Reaction of (6) with anthranilic acid: Synthesis of 2-(\{[(2, 3-dioxo-2, 3-dihydro-1H-indol-1-yl) acetyl $]$ carbamothioyl\} amino) benzoic acid (7)

A solution of anthranilic acid (1.37 g, $10 \mathrm{mmole})$ in $30 \mathrm{ml}$ of dry acetone was added to a solution of the equivalent amount $(2.46 \mathrm{~g}, 10 \mathrm{mmole})$ of isothiocyanates (6) in dry acetone the reaction mixture was refluxed $6 \mathrm{hr}$ and the product obtained recrystallized from ethanol to give (7), m.p $=160-162$, yield $=61 \%$. Anal. Calcd. $\%$ for $\mathrm{C}_{18} \mathrm{H}_{13} \mathrm{~N}_{3} \mathrm{O}_{5} \mathrm{~S}(383)$ : $\mathrm{C}$, 56.39; H, 3.42; N, 10.96. Found\%: C, 56.32; H, 3.47; N, 10.89. IR (KBr) (v $\left.v_{\max }, \mathrm{cm}^{-1}\right)$ : board, 3400-2950 (OH acid, NH, CHaro, CHal), 1703 (CO acid), 1665 (CO imid), 1298 (C=S). MS, m/z (\%): 383 (M+. 0.41).

Cyclization of (7) with freshly acetic anhydride: Synthesis of 1-[2-oxo-2-(4-oxo-2-thioxo-1, 4-dihydroquinazolin3(2H)-yl) ethyl]-1H-indole-2, 3-dione (8).

Compound (7) (1.88 g, 4.9 mmole) was refluxed freshly distilled acetic anhydride (10 ml) for $2 \mathrm{hr}$, then cooled and poured into ice-water the precipitate obtained was filtered off, washed with water and recrystallized from ethanol to give (8), m.p $=108-110$, yield $=77 \%$. Anal. Calcd. \% for $\mathrm{C}_{18} \mathrm{H}_{11} \mathrm{~N}_{3} \mathrm{O}_{4} \mathrm{~S}(365)$ : C, 59.17; H, 3.03; N, 11.50. Found \%: C, 59.15; H, 3.08; N, 11.52.IR (KBr) $\left(v_{\max }, \mathrm{cm}^{-1}\right): 3405(\mathrm{NH}),(1756,1714$, and 1603) two different imides and ketone, $1273(\mathrm{C}=\mathrm{S}) .{ }^{1} \mathrm{HNMR}\left(\mathrm{DMSO}_{\mathrm{d}}\right): \delta 11.05\left(\mathrm{~s}, 1 \mathrm{H}, \mathrm{NH}\right.$, exchangeable with $\left.\mathrm{D}_{2} \mathrm{O}\right), 7.9-7.3(\mathrm{~m}, 8 \mathrm{H}, \mathrm{ArH}), 3.3\left(\mathrm{~s}, 2 \mathrm{H}, \mathrm{CH}_{2}\right)$. $\mathrm{MS}, \mathrm{m} / \mathrm{z}(\%): 365\left(\mathrm{M}^{+}, 0.29\right)$. 
Reaction of (6) with glycine: Synthesis of 2-(2, 3-dioxo-2, 3-dihydro-1H-indol-1-yl)-N-(5-oxo-2-sulfanyl-1, 3oxazolidin-2-yl) acetamide (9)

A solution of isothiocyanates (6) (2.46 g, $10 \mathrm{mmole})$ in dry acetone was added to glycine $(0.75 \mathrm{~g}, 10 \mathrm{mmole})$ in dry acetone and few drops of dry pyridine. The reaction mixture was refluxed for $6 \mathrm{hr}$, and then cooled to room temperature. The solid product formed was filtered off and recrystallized from ethanol to give (9), m.p $=268-270$, yield $=78 \%$. Anal. Calcd. \% for $\mathrm{C}_{13} \mathrm{H}_{11} \mathrm{~N}_{3} \mathrm{O}_{5} \mathrm{~S}$ (321): C, 48.59; H, 3.45; N, 13.08. Found \%: C, 48.62; H, 3.39; N, 13.02. IR (KBr) $\left(v_{\max }, \mathrm{cm}^{-1}\right): 3382,3174(\mathrm{NH}), 1713\left(\mathrm{C}=\mathrm{O}\right.$ of lacton), $1615\left(\mathrm{C}=\mathrm{O}\right.$ of imid), $2050(\mathrm{SH}) .{ }^{1}$ HNMR $\left(\mathrm{DMSO}-\mathrm{d}_{6}\right): \delta 10.9(\mathrm{~s}$, $1 \mathrm{H}, \mathrm{NH}$ exchangeable with $\left.\mathrm{D}_{2} \mathrm{O}\right), 10.2\left(\mathrm{~s}, 1 \mathrm{H}, 1 \mathrm{NH}\right.$, exchangeable with $\left.\mathrm{D}_{2} \mathrm{O}\right)$ 7.3-6.7 (s, 1H, SH, m, 4H, ArH), $2.8(\mathrm{~s}$, $\left.2 \mathrm{H}, \mathrm{CH}_{2}-\mathrm{NH}\right), 3.5$ (s, $\left.2 \mathrm{H}, \mathrm{CH}_{2}-\mathrm{CO}\right)$. MS, m/z (\%): $321\left(\mathrm{M}^{+}, 76.8\right)$.

Reaction of (6) with benzoyl glycine: Synthesis of [\{[(2, 3-dioxo-2, 3-dihydro-1H-indol-1-yl) acetyl] carbamothioyl\} (benzoyl) amino] acetic acid (10)

A solution of isothiocyanates $(2.46 \mathrm{~g}, 10 \mathrm{mmole})$ in dry acetone was added to benzoyl glycine $(1.79 \mathrm{~g}, 10 \mathrm{mmole})$ in dry pyridine. The reaction mixture was refluxed $6 \mathrm{hr}$, then cooled and poured into ice-water/cold dil HCl. The precipitate obtained was filtered off, washed with water and recrystallized from ethanol to give (10), m.p $=255-257$, yield $=62 \%$. Anal. Calcd. \% for $\mathrm{C}_{20} \mathrm{H}_{15} \mathrm{~N}_{3} \mathrm{O}_{6} \mathrm{~S}(425)$ : C, 56.47; H, 3.55; N, 9.88. Found \%: C, 56.44; H, 3.57; N, 9.91. IR (KBr) (v $v_{\max }$, $\left.\mathrm{cm}^{-1}\right)$ : board $3401(\mathrm{OH}), 3255(\mathrm{NH}), 1715\left(\mathrm{C}=\mathrm{O}\right.$ of a cid), $1616\left(\mathrm{C}=\mathrm{O}\right.$ of imid), $1323(\mathrm{C}=\mathrm{S}) .{ }^{1} \mathrm{HNMR}\left(\mathrm{DMSO}-\mathrm{d}_{6}\right): \delta$ $11.4\left(\mathrm{~s}, 1 \mathrm{H}, \mathrm{OH}\right.$ exchangeable with $\left.\mathrm{D}_{2} \mathrm{O}\right), 10.9\left(\mathrm{~s}, 1 \mathrm{H}, 1 \mathrm{NH}\right.$, exchangeable with $\left.\mathrm{D}_{2} \mathrm{O}\right)$ 7.6-6.8 $(\mathrm{m}, 9 \mathrm{H}, \mathrm{ArH}), 3.4(\mathrm{~s}, 2 \mathrm{H}$, $\left.\mathrm{CH}_{2}-\mathrm{CO}\right), 2.5\left(\mathrm{~s}, 2 \mathrm{H}, \mathrm{CH}_{2}-\mathrm{N}\right)$. MS, m/z (\%): $425\left(\mathrm{M}^{+}, 19.75\right)$.

Cyclization of (10) with freshly acetic anhydride: Synthesis of 1-\{2-oxo-2-[5-oxo-3-(benzoyl)-2thioxoimidazolidin-1-yl] ethyl\}-1 $\boldsymbol{H}$-indole-2, 3-dione (11)

Compound (10) (2.08 g, 4.89 mmole) was refluxed in freshly distilled acetic anhydride $(10 \mathrm{ml})$ for $2 \mathrm{hr}$. Then cooled and poured into ice-water The precipitate obtained was filtered off, washed with water and recrystallized from $\left(\mathrm{DMF} /\right.$ water) to give (11), m.p $=176-178$, yield $=87 \%$. Anal. Calcd. $\%$ for $\mathrm{C}_{20} \mathrm{H}_{13} \mathrm{~N}_{3} \mathrm{O}_{5} \mathrm{~S}$ (407): C, 58.96; H, 3.22; $\mathrm{N}$, 10.13. Found \%: C, 58.90; H, 3.29; N, 10.08. IR $(\mathrm{KBr})\left(v_{\max }, \mathrm{cm}^{-1}\right): 1716(\mathrm{C}=\mathrm{O}$ of ketone), $1604(\mathrm{C}=\mathrm{O}$ of imid $), 1278$ $(\mathrm{C}=\mathrm{S}) .{ }^{1} \mathrm{HNMR}$ (DMSO-d $\left.{ }_{6}\right): 8.2-7.6(\mathrm{~m}, 9 \mathrm{H}, \mathrm{ArH}), 3.3\left(\mathrm{~s}, 2 \mathrm{H}, \mathrm{CH}_{2}-\mathrm{CON}\right) 2.5$ (s, 2H, $\left.\mathrm{CH}_{2}-\mathrm{COPh}\right) . \mathrm{MS}, \mathrm{m} / \mathrm{z}(\%): 407$ $\left(\mathrm{M}^{+}, 2.55\right)$.

Reaction of (6) with hydrazine hydrate: Synthesis of 2-(2, 3-dioxo-2, 3-dihydro-1H-indol-1-yl)- $\mathrm{N}$ (hydrazinocarbonothioyl) acetamide (12)

A solution of isothiocyanates $(2.46 \mathrm{~g}, 10 \mathrm{mmole})$ in dry acetone was added to hydrazine hydrate $(0.5 \mathrm{ml}, 10 \mathrm{mmole})$ in dry benzene. The reaction mixture was heated under reflux for $6 \mathrm{hr}$. The solid product was filtered off and recrystallized form ethanol to give (12), m.p $=150-152$, yield $=89 \%$. Anal. Calcd. $\%$ for $\mathrm{C}_{11} \mathrm{H}_{10} \mathrm{~N}_{4} \mathrm{O}_{3} \mathrm{~S}(278)$ : C, 47.48; H, 3.62; $\mathrm{N}$, 20.13. Found \%: C, 47.41; H, 3.54; N, 20.19. IR $(\mathrm{KBr})\left(v_{\max }, \mathrm{cm}^{-1}\right): 3381\left(\mathrm{NH}_{2}\right), 3163(\mathrm{NH}), 1691(\mathrm{C}=\mathrm{O}$ of amid $), 1621$ $\left(\mathrm{C}=\mathrm{O}\right.$ of amid), $1335(\mathrm{C}=\mathrm{S}) .{ }^{1} \mathrm{HNMR}\left(\mathrm{DMSO}_{6}\right)$ : $\delta 7.353\left(\mathrm{~s}, 1 \mathrm{H}, \mathrm{NH}\right.$, exchangeable with $\left.\mathrm{D}_{2} \mathrm{O}\right), 7.182$ and 7,013 $(\mathrm{m}$, $2 \mathrm{H}, \mathrm{NH}_{2}$, exchangeable with $\left.\mathrm{D}_{2} \mathrm{O}\right), 6.963\left(\mathrm{~s}, 1 \mathrm{H}, \mathrm{NH}\right.$, exchangeable with $\left.\mathrm{D}_{2} \mathrm{O}\right), 8.12-6.9(\mathrm{~m}, 4 \mathrm{H}, \mathrm{ArH}), 2.2\left(\mathrm{~s}, 2 \mathrm{H}, \mathrm{CH}_{2}\right)$. MS, $\mathrm{m} / \mathrm{z}(\%): 287\left(\mathrm{M}^{+}, 0.3\right)$.

Cyclization of (12) with freshly acetic anhydride: Synthesis of 1-[(5-thioxo-4, 5-dihydro-1H-1, 2, 4-triazol-3-yl) methyl]-1H-indole-2, 3-dione (13)

A mixture of Compound (12) $(1.41 \mathrm{~g}, 4.91 \mathrm{mmole})$ and freshly distilled acetic anhydride $(10 \mathrm{ml})$ was heated under reflux for $2 \mathrm{hr}$. then cooled and poured into ice-water The precipitate obtained was filtered off, washed with water and recrystallized from (DMF/water ) mixture to give (13), m.p $=112-114$, yield $=83 \%$. Anal. Calcd. $\%$ for $\mathrm{C}_{11} \mathrm{H}_{8} \mathrm{~N}_{4} \mathrm{O}_{2} \mathrm{~S}$ (260): C, 50.76; H, 3.10; N, 21.53. Found \%: C, 50.68; H, 3.21; N, 21.62. IR (KBr) $\left(v_{\max }, \mathrm{cm}^{-1}\right): 3423(\mathrm{NH}), 1712(\mathrm{C}=\mathrm{O}$ of ketone), 1610 ( $\mathrm{C}=\mathrm{O}$ of amid), $1272(\mathrm{C}=\mathrm{S})$. MS, $\mathrm{m} / \mathrm{z}(\%): 260\left(\mathrm{M}^{+}, 1.1\right)$.

Reaction of (6) with phenylhydrazine: Synthesis of 2-(2, 3-dioxo-2, 3-dihydro-1H-indol-1-yl)-N-\{[2-(benzoyl) hydrazine] carbomothioyl\} acetamide (14)

A solution of isothiocyanates $(2.46 \mathrm{~g}, 10$ mmole $)$ in dry acetone was added to phenylhydrazine $(1.36 \mathrm{~g}, 10 \mathrm{mmole})$ in dry acetone. The reaction mixture was heated under reflux for $6 \mathrm{hr}$. The solid product was filtered off and recrystallized form ethanol to give (14), m.p $=211-213$, yield $=89 \%$. Anal. Calcd. \% for $\mathrm{C}_{18} \mathrm{H}_{14} \mathrm{~N}_{4} \mathrm{O}_{4} \mathrm{~S}$ (382): C, 56.54; H, 3.69; N, 14.65. Found \%: C, 56.50; H, 3.77; N, 14.62. IR $(\mathrm{KBr})\left(\mathrm{v}_{\max }, \mathrm{cm}^{-1}\right): 3421(\mathrm{NH}), 3154(\mathrm{NH}), 1719$ of ketone, (1657, 1616) two different imides, $1278(\mathrm{C}=\mathrm{S}) .{ }^{1} \mathrm{HNMR}\left(\mathrm{DMSO}_{\mathrm{d}} \mathrm{d}_{6}\right): \delta 11.05\left(\mathrm{~s}, 1 \mathrm{H}, \mathrm{NH}\right.$ exchangeable with $\left.\mathrm{D}_{2} \mathrm{O}\right), 10.9(\mathrm{~s}, 1 \mathrm{H}$, $\mathrm{NH}$, exchangeable with $\left.\mathrm{D}_{2} \mathrm{O}\right), 10.5\left(\mathrm{~s}, 1 \mathrm{H}, \mathrm{NH}\right.$, exchangeable with $\left.\mathrm{D}_{2} \mathrm{O}\right), 7.9-7.5(\mathrm{~m}, 9 \mathrm{H} \mathrm{ArH}) 3.5\left(\mathrm{~s}, 2 \mathrm{H}, \mathrm{N}-\mathrm{CH}_{2}-\mathrm{CO}\right)$. MS, $\mathrm{m} / \mathrm{z}(\%): 382\left(\mathrm{M}^{+}, 5.83\right)$.

Reaction of (14) with freshly acetic anhydride: Synthesis of 1-[2-oxo-2-(3-phenyl-5-thioxo-1, 5-dihydro-4H-1, 2, 4-triazol-4-yl) ethyl]-1H-indole-2, 3-dione (15)

A mixture of Compound (14) $(1.88 \mathrm{~g}, 4.92 \mathrm{mmole})$ and freshly distilled acetic anhydride $(10 \mathrm{ml})$ was heated under reflux for $2 \mathrm{hr}$. Then cooled and poured into ice-water The precipitate obtained was filtered off, washed with water and recrystallized from ethanol to give (15), m.p=182-183, yield $=69 \%$. Anal. Calcd. $\%$ for $\mathrm{C}_{18} \mathrm{H}_{12} \mathrm{~N}_{4} \mathrm{O}_{3} \mathrm{~S}(364)$ : C, 59.33; $\mathrm{H}$, 3.32; N, 15.38. Found \%: C, 59.26; H, 3.26; N, 15.31. IR $(\mathrm{KBr})\left(v_{\max }, \mathrm{cm}^{-1}\right): 3430(\mathrm{NH}), 1716(\mathrm{C}=\mathrm{O}$ of ketone), 1274 $(\mathrm{C}=\mathrm{S}) . \mathrm{MS}, \mathrm{m} / \mathrm{z}(\%): 364\left(\mathrm{M}^{+}, 0.06\right)$. 
Reaction of (6) with benzoyl glycine with benzaldehehyde: Synthesis of 2-\{1-Benzoyl-3-[2-(2, 3-dioxo-2, 3dihydro-indol-1-yl)-acetyl]-thioureido\}-3-phenyl-acrylic acid (16)

A solution of isothiocyanates $(2.46 \mathrm{~g}, 10 \mathrm{mmole})$ in dry acetone was added to benzoyl glycine $(1.79 \mathrm{~g}, 10 \mathrm{mmole})$ and benzaldehehyde ( $2.65 \mathrm{~g}, 10 \mathrm{mmole})$ in dry pyridine. The reaction mixture was refluxed $6 \mathrm{hr}$, then cooled and poured into ice-water /cold dil $\mathrm{HCl}$. The precipitate obtained was filtered off, washed with water and recrystallized from ethanol to give (16), m.p=251-252, yield $=87 \%$. Anal. Calcd. $\%$ for $\mathrm{C}_{27} \mathrm{H}_{19} \mathrm{~N}_{3} \mathrm{O}_{6} \mathrm{~S}(513)$ : $\mathrm{C}, 63.15 ; \mathrm{H}, 3.73 ; \mathrm{N}, 8.18$. Found \%: $\mathrm{C}$, 63.12; H, 3.77; N, 8.13. IR (KBr) $\left(v_{\max }, \mathrm{cm}^{-1}\right)$ : board $3405(\mathrm{OH}, \mathrm{NH}, \mathrm{CHarom}), 1712(\mathrm{C}=\mathrm{O}$ of a cid $), 1616(\mathrm{C}=\mathrm{O}$ of imid), 1327 (C=S). MS, m/z (\%): $513\left(\mathrm{M}^{+}, 4.14\right)$.

Cyclization of (16) with freshly acetic anhydride: Synthesis of 1-[2-(3-Benzoyl-4-benzylidene-5-oxo-2-thioxoimidazolidin-1-yl)-2-oxo- ethyl]-1H-Indole-2, 3-dione (17)

A mixture of Compound (16) (2.52 g, $4.91 \mathrm{mmole})$ and freshly distilled acetic anhydride (10 ml) was heated under reflux for $2 \mathrm{hr}$. Then cooled and poured into ice-water. The precipitate obtained was filtered off, washed with water and recrystallized from ethanol to give (17), m.p=130-132, yield $=82 \%$. Anal. Calcd. $\%$ for $\mathrm{C}_{27} \mathrm{H}_{17} \mathrm{~N}_{3} \mathrm{O}_{5} \mathrm{~S}$ (495): $\mathrm{C}, 65.45 ; \mathrm{H}$, 3.46; N, 8.48. Found: C, 65.39; H, 3.48; N, 8.41. IR (KBr) $\left(v_{\max }, \mathrm{cm}^{-1}\right): 1714$ (C=O of ketone), 1611 (C=O of amid), $1274(\mathrm{C}=\mathrm{S}) .{ }^{1} \mathrm{HNMR}\left(\mathrm{DMSO}_{6}\right): \delta$ 7.4-6.7 (m, 14H, ArH) $6.4(\mathrm{~s}, 1 \mathrm{H}, \mathrm{CH}=), 2.3\left(\mathrm{~s}, 2 \mathrm{H}, \mathrm{CH}_{2}\right) . \mathrm{MS}, \mathrm{m} / \mathrm{z}(\%): 495\left(\mathrm{M}^{+}\right.$, 1.05).

\section{References}

[1] Dzyubenko, V. G.; Abramenko, P. I.; Zh. Vses Khim. Ova. Im. D. I. Mendeleeva. (1986), 31, 229.

[2] Tomchim, A. B.; shirokii, G. A.; Zh .Org. Khim. (1977), 13, 404.

[3] Rothkopf, H. W.; Wohrle, D.; Muller, R.; Kobmehl, G.; Chem. Ber. (1975), 108, 875.

[4] Bergman, J.; Eklund, N.; Tetrahedron. (1980), 36, 1445.

[5] Cornforth, J. W.; Hitchcock, P. B.; Rozos, P.; J. Chem. Soc. Perkin Trans. (1996), 1, 2787.

[6] Abdel- Rahman, R. M.; Abdel Halim, N. M.; Ibrahim, S. S.; Mohamed, E. A.; J. Chem. Soc. Pak. (1987), 9, 523.

[7] Abdel- Rahman, R. M.; EL-Gendy, Z.; Mohamoud, M. B.; Indian J. Chem. (1990), 29 B, 352.

[8] Abdel- Rahman, R. M.; Islam, I. E.; EL-Gendy, Z.; J. Indian Chem. Soc. (1991), 68, 621.

[9] Abdel- Rahman, R. M.; EL-Gendy, z.; Fawzy, M. M.; Asian J. Chem. (1992), 4 (2), 364 -371.

[10] Abdel- Rahman, R. M.; Fawzy, M. M.; EL-Gendy, z.; Asian J. Chem. (1992), 4 (3), 534-543.

[11] Venkataramana, C. H. S.; Ramya Sravani, K. M.; Swetha Singh, S.; Madhavan, V.; Journal of Pharmacy Research (2012), 5(2), 760-764.

[12] Ahadi, S.; Moafi, L.; Feiz, A.; Bazgir, A.; Tetrahedron (2011), 67, 3954-3958.

[13] Liu, G. G.; Zhao, H.; Lan, Y. -B.; Wu, B.; Huang, X. -F.; Chen, J.; Tao, J. -C.; Wang, X. -W.; Tetrahedron (2012), 68, $3843-3850$.

[14] Sun, Y.; Sun, J.; Yan, C.-G.; Beilstein J. Org. Chem. (2013), 9, 8-14.

[15] Abdel- Rahman, R. M.; Boll. Chim. Farm. (2001), 140, 401.

[16] Bhanupriya, B.; Devender, P.; Nadeem, S.; Shamsher, M. A.; Waquar, A.; International Journal of Pharmaceutical Sciences and Drug Research ( IJPSDR ) (2010), 2(4), 229-235.

[17] Manna, K.; Aggarwal, Y.; Bioorg. Med. Chem. Lett. (2009), 19, 2688-2692.

[18] Olomola, T. O.; Bada, D. A.; Toxi. Environ. Chem. (2009), 91(5), 941-946.

[19] Bauer, A. W.; Kirby, W. M.; Sherris, C.; Turck, M.; American Journal of Clinical Pathology, (1966), 45, 493-496.

[20] Pfaller, M. A.; Burmeister, L.; Bartlett, M. A.; Rinaldi, M. G.; J .Clin. Microbiol (1988), 26, 1437-1441.

[21] National Committee for Clinical Laboratory Standards. (1993). Performance VOL. 41, (1997) antimicrobial susceptibility of Flavobacteria.

[22] National Committee for Clinical Laboratory Standards. (2002). Reference Method for Broth Dilution Antifungal Susceptibility Testing of Conidium -Forming filamentous Fungi: Proposed Standard M38-A. NCCLS, Wayne, PA, USA.

[23] National Committee for Clinical Laboratory Standards. (2003). Method for antifungal Disk diffusion Susceptibility Testing of Yeast: Proposed Guideline M44-p.NCCLS, Wayne, pa, USA.

[24] National Committee for Clinical Laboratory Standards. (1993). Mehods for dilution antimicrobial susceptibility tests for bacteria that grow aerobically. Approved standard M3- A3. National Committee for Clinical Laboratory Standards, Villanova, pa.

[25] Liebowitz, L. D.; Ashbee, H. R.; Evans, E. G. V.; Chong, Y.; Mallatova, N.; Zaidi, M.; Gibbs, D. and Global Antifungal Surveillance Group; Diagn. Microbiol. Infect .Dis. (2001), 4, 27-33.

[26] Matar, M. J., Ostrosky-Zeichner, L.; Paetznick, V. L.; Rodriguez, J. R.; Chen, E.; Rex, J. H.; Antimicrob. Agents Chemother (2003), 47, 16471651. 